\title{
Intrapreneurial behaviors and innovative performance: The moderating role of employees' characteristics in commercial banks
}

\author{
Omar Radwan ALmasri ${ }^{\mathrm{a}^{*}}$ and Alaeddin Mohammed Khalaf Ahmad
}

${ }^{a}$ Princess Sumaya University for Technology, Jordan

\begin{tabular}{l}
\hline C H R O N I C L E \\
\hline Article history: \\
Received May 182020 \\
Received in revised format May \\
262020 \\
Accepted July 182020 \\
Available online \\
July 182020 \\
\hline Keywords: \\
Intrapreneurial Behaviors \\
Innovative Performance \\
Employee Characteristics \\
Commercial Banks \\
Jordan
\end{tabular}

\section{Introduction}

Entrepreneurship pathways are needed to achieve excellence for banks. One of these ways is to give employees a space in which to engage in entrepreneurial work, extract entrepreneurial ideas from them, and exploit entrepreneurial staff for the benefit of the organization (Phogat, S. 2016; Minh \& Thanh, 2020). According to Foss et al. (2015) relying on employees who are proactive and creative rather than those who only follow instructions is critical. Employees who only follow instructions cannot be creative and change how a company works for the better. This results in the growth of activity between employees and a company and the exchange of ideas and a vision of topics and market. Heinze and Weber (2016) found that good employees exploit any change that occurs in a company to benefit from it and expand the work of the company and, therefore, benefits both parties. Also, Alt and Craig (2016) showed that lower-level employees should not be neglected, because creativity does not know ranks and lower-level employees can provide ideas from their immediate surroundings that can have positive effects on production. Over time, the consideration of entrepreneurship has morphed into a study of what has been termed "intrapreneurship," which is a system that permits employees to act like an entrepreneur within a company or organization (Sebora \& Theerapatvong, 2019). Berzin and Pitt-Catsouphes (2015) described corporate "intrapreneurship" as creativity processes in which an employee within a company develops useful ideas for the company. Heinze and Weber (2016) found that "intrapreneurial employees implement new logics in organizations by using opportunistic tactics, and leverage small changes to spark larger changes in the broader organization" (p. 157). The current research was conducted to understand the impact of intrapreneurial behaviors on the

* Corresponding author.

E-mail address: eng.orm@gmail.com (O. R. ALmasri)

(C) 2020 by the authors; licensee Growing Science, Canada doi: $10.5267 /$ j.ac.2020.7.018

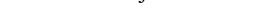


innovative performance of commercial banks in Jordan and to study why a range of performance differences are present among the bank employees. This was done by studying variables that help in understanding the innovative performance of banks through employees' behaviors like innovativeness, risk-taking, proactiveness, and networking and by examining employees' characteristics like organized responsibility, effective communication, and alertness and awareness. The research problem revolves around studying the factors behind intrapreneurial behaviors that impact the innovative performance of banks in Jordan. This research aims to explore employees' intrapreneurial behaviors and employees' characteristics that affect the innovative performance of banks in Jordan.

\section{Literature Review}

\subsection{Theories of Intrapreneurship}

Intrapreneurship theories that have aroused interest in applications and research (Alpkan, et al., 2010; Augusto et al., 2012; Neessen, et al., 2019). Alpkan et al. (2010) linked organizational support factors, including management support, allocation of free time, work discretion, rewards and risk-taking, and their effect on innovative performance moderated by human capital. Augusto, et al. (2012) explored the relationship between intrapreneurship and firm performance, which presents their model. The concept of intrapreneurship is explained by six factors: innovation, risk/uncertainty, risk/challenges, competitive energy, proactiveness and autonomy, productivity, improvement, financial performance, and growth. Neessen et al. (2019) analyzed and classified intrapreneurship concepts into behaviors, characteristics, and attitudes. The characteristics and attitudes were considered precedents of behaviors. Current researchers have identified intrapreneurship as recognizing an employee's opportunities and exploiting them; they are innovativeness, risk-taking, proactive and networking, that lead to create a new competitive power, new product, service, or method of work that improves the organization's performance. When employees within an organization are entrepreneurs that impacts organization-wide results, such as new products and self-renewal. It changes the performance of the company, in terms of creating new values, growth, innovative efforts, revenue, or sustainable efforts. An organization can provide resources and knowledge.

\subsection{Intrapreneurial Behaviors}

In the context of corporate studies, entrepreneurship inside a corporation has been termed intrapreneurship or internal entrepreneurship. An intrapreneurial orientation indicates that key dimensions of innovation include proactiveness, and risktaking, with economic gains as a key incentive (Morris, Webb, \& Franklin, 2011). Morris, et al. (2011) argued that, if a company or non-profit organization is working, new perceptions of such motivations are needed. When institutions are aware of how individual behavior leads to innovation, this knowledge leads to an improvement in the organization's entrepreneurial level by the ability to motivate staff to contribute useful ideas (Kassa \& Raju, 2015). Factors such as innovativeness, risk-taking, proactiveness, and networking may be important in the process, and the strength of a person's relationship with a team may be influential on the team as a whole and the strength of performance of that team (Neessen, et al., 2019). Farrukh et al. (2017) examined organizational commitment and entrepreneurial behavior and found that and affective commitment (AC) and normative commitment (NC) have positive and significant impacts on intrapreneurial behavior. Fellnhofer (2017) determined that strategic orientation, resource orientation, management structure, reward philosophy, growth orientation, and entrepreneurial have a significant and positive impact on a firm's innovation success. Laila and Hanif (2017) focused on emotional commitment more than other types of commitment. Corporate entrepreneurship or intrapreneurship is always looking for how to obtain the best possible output of an employees and exploit the capabilities of the staff to achieve greater successes (Afshar Jahanshahi et al., 2018). An organization's strategy may be to clarify and communicate the data that the top management is issuing and, thus, achieves the goals (Dipboye, 2018). A change agent is an individual instigating and manages change in an organization. In an organization, change agents like transformational leaders have forceful impacts. For example, Afsar and Umrani (2019) found that transformational leadership had a positive impact on employees' innovative work behavior and motivation. Based on the discussion of intrapreneur behaviors, the following hypothesis is posited.

H1: There is a significant positive relationship between intrapreneurial behaviors in commercial banks, and their innovative performance.

\subsubsection{Innovativeness}

Employees' behavior increases support for plans and strategies through staff ownership of creative capabilities according to strategic HRM theories (Kaifeng, et al., 2012). The effectiveness of management in creating desirable attitudes depends on the characteristics of the knowledge concerned. First, types of control impact how information is shared and knowledge is disseminated within organizations, whether the mechanisms encompass routines, coordination, organizational norms, or structured relationships between individuals or groups (Turner \& Makhija, 2006) second, controls create incentives and disincentives for team members that are consistent with project goals and objectives. Because meeting goals and objectives requires the use of knowledge by team members, the purposeful structuring of control, in turn, directs the type of knowledge 
integration behavior exhibited (Turner \& Makhija, 2006). This control fosters communication between the organizational members and motivates them to gain new skills and the knowledge necessary to master the predefined tasks and to realize the common goals of the organization (Turner \& Makhija, 2006). When an idea is innovative, that idea must be able to be replicated at an appropriate cost and to meet the needs of the customer. Innovation involves generating new ideas and transforming them into useful products in business. Innovation involves information, imagination, and initiatives for devising more extensive and different resources. When a company encourages or insists on employees to meet the growing needs and expectations of customers, then that company gets innovative results (Meyer, 2007). Based on the above, the following hypothesis is posited.

H1a: There is a significant positive relationship between innovativeness in commercial banks, and their innovative performance.

\subsubsection{Risk-taking}

Risk has been seen as a critical component of entrepreneurship since Cantillon (1734), who first conceived of an entrepreneur, as a risk-taker. In the context of enterprises, (Fellnhofer, et al. 2017) viewed risk-taking in terms of top management orientation in pursuing enhanced competitiveness and include initiative and risk-taking, and competitive aggressiveness, and boldness. Thus, risk-taking in business concerns internal leadership in the sense of risks that are derived from actions within in institution in which efforts and resources must be invested before the results of their return are known. In the context of enterprises, Farrukh, et al. (2017) defined employees' risk-taking behavior as the search for courageous suggestions for the benefit of an organization, in which the results of these proposals are uncertain. Kollmann et al. (2017) argued that, when some organization members decide a potential loss, a negative opinion may arise among risk-averse individuals as this danger may affect their work. Thus, emotional tensions are likely to be present between opponents and supporters. In a systematic review of the literature, Neessen et al. (2019) focused on the intrapreneurial employees. They found that innovativeness, proactiveness, risk-taking, opportunity recognition, and external networking were vital behavioral dimensions of intrapreneurship. Kelley, et al. (2011) stressed that it is preferable to identify people who can take risks and make it difficult to stop a project simply because that project has risks. That is because resources can turn the failure into success, and people seek to turn weaknesses into strengths. In this environment, actual leaders do not punish employees simply because they failed in their attempts to create an innovation that seeks to improve the organization. A bank must have a leader who can deal with risk and uncertain results. This type of manager gradually gets closer to leading to the success of the company and creating something that benefits a bank tremendously. Kollmann et al. (2017) argued that, when some organization members decide a potential loss, a negative opinion may arise among risk-averse individuals as this danger may affect their work. Thus, emotional tensions are likely to be present between opponents and supporters. The existence of such a difference in the perception of risk among the members of the organization leads to the exchange of information between the members. However, fruitful results may occur because a person is a small risk-taker because his/her suggestions of negative prospects may be useful for making changes in a project before getting starting, so the consultations are good even if differences exist in various viewpoints. As a result of the discussion above, the following hypothesis is posited.

H1b: There is a significant positive relationship between risk-taking in commercial banks, and their innovative performance.

\subsubsection{Proactiveness}

Chen et al. (2015) concluded that it is necessary to identify employees who are proactive through senior managers and corporate leaders. Proactive employees should be encouraged to communicate more because of the essential role played by employees in anticipation of a future work environment. Dickel (2017) noted that that proactiveness varies from company to company, depending on the type of company, the extent of the company's support for individual entrepreneurship, the degree of proactive engagement with the risk ratio, the company's ability to withstand risk and employees support, company size and scope of corporate competition. When internal entrepreneurs challenge the current situation within organizations or act proactively, they are likely to bypass standard job descriptions or attempt to sell ideas that are considered controversial within the institutional framework (Parker \& Collins, 2010). Hornsby et al. (2009) assumed that for a bank to be effective in the long term there should be a leadership approach in addition to providing entrepreneurship at all levels of management in the bank. This enhances competitiveness by looking for ways in which the bank excels compared to competitors, which leads to attention to the role of the individual employees and the attempt to determine future ideas. Therein lays the importance of management at the bank level and also the importance of the role of proactive employees. Thus, the following hypothesis is posited.

H1c: There is a significant positive relationship between proactiveness in commercial banks, and their innovative performance.

\subsubsection{Networking}

Chen, et al. (2015) found that the networking of employees plays a key role in building entrepreneurship and in the synthesis and negotiation of many activities and conflicts. These relate to the guidance and ability of medium-project managers to communicate with essential actors inside and outside of an organization. Based on the interactive perspective, business-oriented 
projects and active networks have a higher chance of achieving creative ideas. Mustafa, et al. (2016) found that networking is a vital resource through which sustainable competitive advantages can develop a bank. To fully identify and use the networking of people, banks must have the ability to transfer expertise from the people who have that expertise to the junior staff so that knowledge can spread and be retained in all parts of the bank. Van Dam et al. (2010) said that communication skills refer to individual competence in developing relationships with people who can help at work. Entrepreneurs should network with individuals both inside and outside the organization to facilitate the transfer and access to required information and benefit from expertise. Such is essential for the success of a start-up company. Thus, the expectation is that a positive relationship exists between networking and intrapreneurial behavior. Based on the discussion above, the following hypothesis is posited.

H1d: There is a significant positive relationship between networking in commercial banks, and their innovative performance.

\subsection{Employees Characteristics}

This research addressing employees' characteristics that play essential roles in producing benefit for a bank. Among these characteristics are a well-organized personality, effective communication, and alertness, and awareness. However, when people are exposed to labor-related stress, they often feel tense and upset. The World Health Organization (WHO) (2005) has stated that most people in industrialized countries have devised coping strategies and have become more aware of the effects of labourrelated stress. Because of globalization and changes like work, people working in banks must deal with the increasing pressures associated with work. Professional bank employees must deal with tremendous work pressure, take responsibility, be effective in dealing with multiple processes, and be detail-oriented. At the same time, employees who have high skills in the banking business can manage and maintain records and paperwork accurately, which affects positively on improving a bank's performance (Panda \& Leepsa, 2019). Dipboye (2018) concluded that the characteristics of employees could affect other employees. When an employee is tired and frustrated, this moves like an infection to other employees, and the environment becomes negative. Falcão, et al. (2018) explored personality factors and decision making. They found that the ability to organize in a systematic, orderly way was important. Meng and Berger (2012) conducted that appropriate communication skills when dealing with customers increased the market value of a bank. Thus, the effectiveness of communication is critical. According to Meng and Berger (2012), a bank's potential growth, investor opportunities, and results are often disseminated through a bank's internal communications. Banks have realized the high value of effective internal communication leading to excellent employees' performance, innovation, and productivity as a concept that impacts organizational effectiveness (Morris, 2010). Young (2018) found that, when a bank tries to make more profits, significant changes will be required, and customer support is necessary. In this process, a bank will connect with existing customers, try to contact and gain new customers, so an employee must have the right characteristics to correctly contact with potential customers and convince them to work with the bank. In the context of banking, Pattinson, et al. (2017) defined awareness as employees' knowledge of the information security policies and procedures of the bank that he/she works in and all aspects that relate to the security of an information system, and the attitude of employees to comply with them. Banks must be committed to protecting a client's financial information. Ramlall (2018) mentioned that a good bank employee uses risk indicators to alert the bank about changes that may be considered as a risk or threat to the bank, based on prior data and supplementing them with sources of information such as quarterly or annual reports. An overall assessment is considered to be a useful analysis. Thus, in light of the above discussion, the following hypothesis is posited.

H2: There is a significant positive relationship between good characteristics of banking employees, and the impact of intrapreneurial behaviors on the innovative performance of commercial banks.

\subsection{The Innovative Performance of Commercial Banks}

Today's banking customers can communicate easily with banks anywhere, so customers can have enough information about any bank they want. Information on customers should be gathered and used in an innovation process with efficient and knowledgeable staff. Innovation is the creation of new products, services, or methods to facilitate and improve corporate operations. Wang and Wang (2012) proposed two important elements of innovation. They are innovation quality and innovation speed. The speed of innovation is the period between initial development and the final marketing of new products or services.

\section{Research Methodology}

\subsection{Research Design}

A quantitative method was used to collect primary data through a research questionnaire, which was administered to banking employees in Jordan. A purposive sampling technique was used to choose the participants in this research. This research uses an in-depth survey instrument approach to understand the relationship between independent variables and dependent variables and aims to determine the impact of intrapreneurial behaviors on the innovative performance of banks in Jordan. This research 
uses the hypothetic-deductive method to conclude the questions it aims to answer. The hypothetic-deductive method is a multistep logical method to conclude an answer or solution to a proposed hypothesis (Gemes, 2005).

\subsection{Research questionnaire}

The framework used for this assessment was based on Alpkan, et al.'s model (2010), Augusto, et al.'s model (2012), and Neessen, et al.'s model (2019) of intrapreneurship. The statements in the survey were in previous studies related to the subject of this research. Table 1 shows the statements and their sources.

\section{Table 1}

Research Questionnaire Statements

\begin{tabular}{|c|c|c|}
\hline Statement & To Measure & Source \\
\hline I'm prepared to fight competition by all means necessary. & Risk Taking & \multirow{5}{*}{$\begin{array}{l}\text { Adopted from } \\
\text { Alpkan, et al. } \\
(2010)\end{array}$} \\
\hline When starting a new undertaking, I feel it is worth the risk as I will be able to prove myself. & Risk Taking & \\
\hline Facing the opinion of the majority in my bank does not matter to me. & Risk Taking & \\
\hline I will always be determined to accept the challenge. & Risk Taking & \\
\hline My intrapreneurial behaviors can affect positively the quality of the new service introduced. & Innovative Performance & \\
\hline I contribute to ideas that help my bank to perform better. & Innovativeness & \multirow{8}{*}{$\begin{array}{l}\text { Adopted from } \\
\text { Augusto, et } \\
\text { al. (2012) }\end{array}$} \\
\hline Employees in my bank are encouraged to offer innovative ideas. & Innovativeness & \\
\hline There is a specialized committee in my bank that receives and evaluates creative ideas. & Innovativeness & \\
\hline The term risk-taker is considered a positive attribute for people in my bank. & Risk Taking & \\
\hline I spend time identifying long-range goals for myself. & Proactiveness & \\
\hline I feel in charge of making things happen. & Proactiveness & \\
\hline I feel driven by my personal values. & Proactiveness & \\
\hline $\begin{array}{l}\text { My intrapreneurial behaviors can affect the percentage of new services in the existing product portfolio } \\
\text { positively. }\end{array}$ & Innovative Performance & \\
\hline I propose innovative ideas that improve or change a particular task in my bank to the best. & Innovativeness & \multirow{4}{*}{$\begin{array}{l}\text { Adopted from } \\
\text { Taştan and } \\
\text { Güçel (2014) }\end{array}$} \\
\hline I'm always alerted to any threat to the financial system. & $\begin{array}{l}\text { Employees } \\
\text { Characteristics } \\
\text { (Alertness) }\end{array}$ & \\
\hline I'm always aware of the changes in the financial sector. & $\begin{array}{l}\text { Employees } \\
\text { Characteristics } \\
\text { (Awareness) }\end{array}$ & \\
\hline My intrapreneurial behaviors can affect the number of new service projects positively. & Innovative Performance & \\
\hline I can deal with great pressure. & \multirow{4}{*}{$\begin{array}{l}\text { Employees } \\
\text { Characteristics } \\
\text { (Organized Personality) }\end{array}$} & \multirow{6}{*}{$\begin{array}{l}\text { Adopted from } \\
\text { Phogat } \\
(2016)\end{array}$} \\
\hline I can deal with numerous responsibilities. & & \\
\hline I can be efficient in managing multiple tasks. & & \\
\hline I have attention to records and documentation. & & \\
\hline I have excellent written and verbal communication skills. & \multirow{2}{*}{$\begin{array}{l}\text { Employees } \\
\text { Characteristics } \\
\text { (Effective } \\
\text { Communication) }\end{array}$} & \\
\hline I can communicate financial matters to my colleagues without any confusion. & & \\
\hline If I were able to contribute more ideas, it would motivate me more to stay in my bank. & Innovativeness & \multirow{5}{*}{$\begin{array}{l}\text { Adopted from } \\
\text { Vargas- } \\
\text { Halabí (2017) }\end{array}$} \\
\hline I'm able to choose my actions. & \multirow[t]{2}{*}{ Proactiveness } & \\
\hline There are abundant opportunities that await me. & & \\
\hline I tend to know more new people. & \multirow[t]{2}{*}{ Networking } & \\
\hline I keep in touch with my friends. & & \\
\hline $\begin{array}{l}\text { Individual risk-takers often recognize for their willingness to champion new projects, whether eventually } \\
\text { successful or not. }\end{array}$ & \multirow[t]{2}{*}{ Risk Taking } & \multirow{8}{*}{$\begin{array}{l}\text { Adopted from } \\
\text { Neessen, et } \\
\text { al. (2019) }\end{array}$} \\
\hline Money is often available in my bank to get new project ideas off the ground. & & \\
\hline I have friends that have known through certain activities. & \multirow[t]{5}{*}{ Networking } & \\
\hline It is not a problem for me to know people from different cultures. & & \\
\hline I contact with new friends through social media. & & \\
\hline My network is growing. & & \\
\hline I keep in touch with my colleagues. & & \\
\hline $\begin{array}{l}\text { My intrapreneurial behaviors can affect the ability to introduce new services to the market before competitors. } \\
\text { My intrapreneurial behaviors can affect positively on innovations introduced for work processes and methods. }\end{array}$ & Innovative Performance & \\
\hline
\end{tabular}

\subsection{Research Population and sample}

The population of this research consists of Jordanian and non-Jordanian commercial bankers in Jordan who was 18 to more than 50 years old that work in different banks and different cities in Jordan. To estimate the size of the sample for this study, information was obtained from the Association of Banks in Jordan in 2018. Jordan has 21 commercial banks; 9 of them are Jordanian commercial banks and 12 non-Jordanian commercial banks. The number of all branches of commercial banks in Jordan at that time was 676, most of which were located in Amman, and the number of employees was 18,858. Based on elementary sampling theory and its sampling table too chose the size of this research sample respondent's wit margin of error \pm 
$5 \%$, the research sample consisted of 372 banking employees to whom surveys were distributed. Of these, 242 valid responded, which represents a response rate of $65 \%$.

\subsection{Study Tool Reliability}

Table 2 shows the Cranach's alpha values, which were used to determine the internal consistency reliability of the elements. Reliability should be (0.60) or higher to indicate adequate convergence or internal consistency (Sekaran \& Bougie, 2010).

\section{Table 2}

Reliability of Questionnaire Dimensions

\begin{tabular}{|c|c|c|c|}
\hline No. & Variable $\quad$ Dimension & No of items & Cranach's alpha \\
\hline \multirow[t]{5}{*}{1} & Intrapreneurial Behaviors & 24 & 85.2 \\
\hline & $1 \quad$ Innovativeness & 5 & 75.3 \\
\hline & Risk-Taking & 7 & 78.6 \\
\hline & Proactiveness & 5 & 82.0 \\
\hline & Networking & 7 & 82.9 \\
\hline 2 & Employees Characteristics & 8 & 84.7 \\
\hline 3 & Banks Innovative Performance & 5 & 89.5 \\
\hline & All Questionnaires & 37 & $90.1 \%$ \\
\hline
\end{tabular}

\section{Data Analysis}

\subsection{Demographic Data Analysis}

In our survey, $117(48.3 \%)$ of the participants were male, $125(51.7 \%)$ of them were female and they were all Jordanians. Fig. 1 summarizes other personal characteristics of the participants.

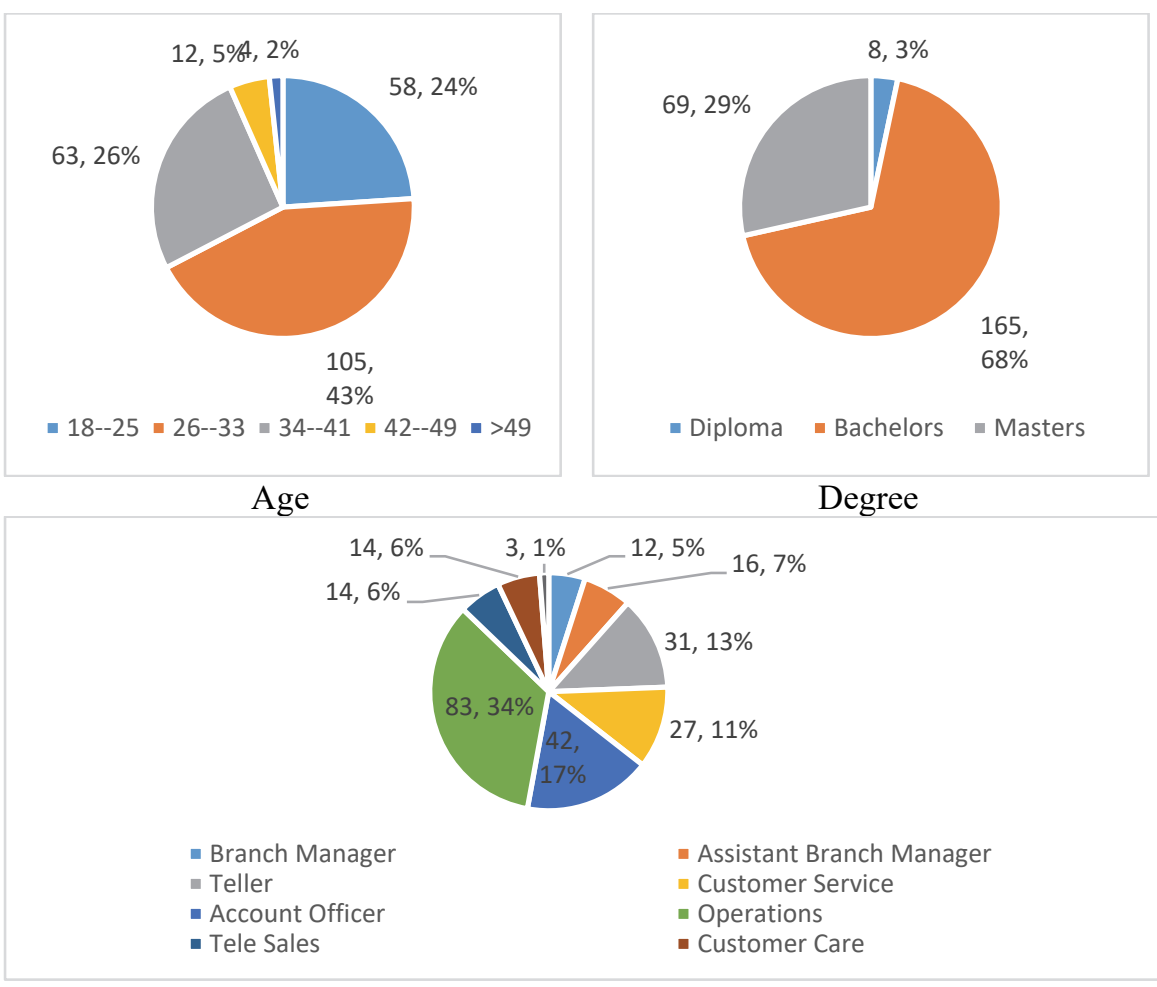

Job position

Fig. 1. Demographic Data

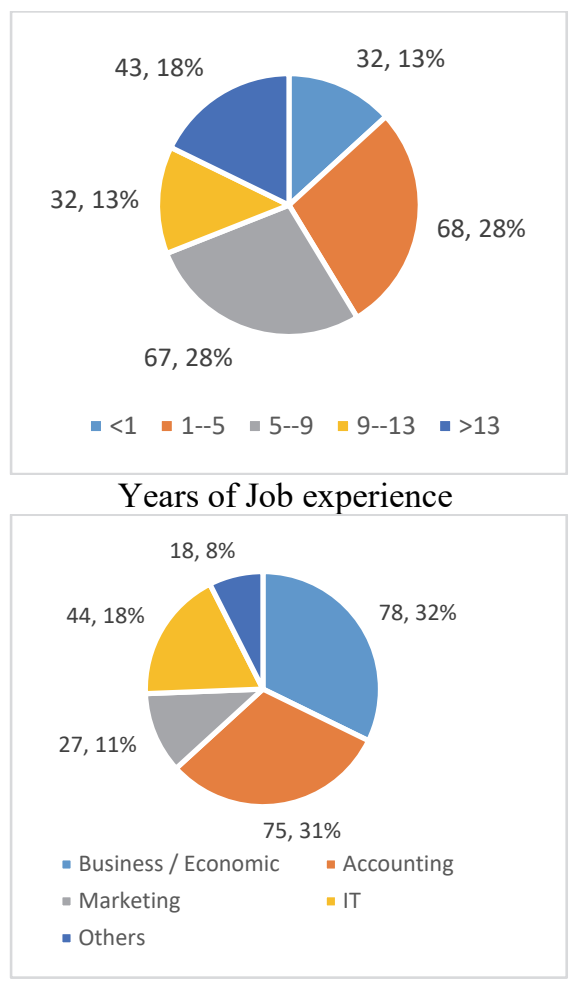

Educational background

\subsection{Descriptive Analysis}

The mean score of the total intrapreneurial behaviors variable is 3.787 with a standard deviation of 0.543 while the descriptive data is as follows for intrapreneurial behaviors dimensions (3.75, 358, 3.81, and 3.99). All dimensions are high except risk taking is medium (3.588). 
Table 3

Overall Means and Standard Deviations of Research Dimensions

\begin{tabular}{|c|c|c|c|c|c|}
\hline No & Dimensions & Mean & SD & Importance & Rank \\
\hline 1 & Innovativeness & 3.759 & 0.520 & High & 3 \\
\hline 2 & Risk Taking & 3.588 & 0.407 & Medium & 4 \\
\hline 3 & Proactiveness & 3.812 & 0.636 & High & 2 \\
\hline \multirow[t]{2}{*}{4} & Networking & 3.992 & 0.533 & High & 1 \\
\hline & Intrapreneurial Behaviors & 3.787 & 0.543 & High & \\
\hline 5 & Employees Characteristics & 3.977 & 0.449 & High & \\
\hline 6 & Banks Innovative Performance & 3.827 & 0.505 & High & \\
\hline
\end{tabular}

\subsection{Analysis Adequacy of the Data to Test the Study Hypotheses}

Before testing the hypotheses of the study, tests were conducted to ensure the adequacy of the data in meeting the assumptions necessary for regression analysis. These confirmed that no high correlations existed between the independent variables Multicolinearity using the variance inflation factor (VIF) and test tolerance for each variable of the study variables were conducted. The variance inflation factor did not exceed the allowable value of 10 , and the tolerance values were more than 0.0 . To ensure that the data had a normal distribution calculates, the skewness coefficient was. Data are normal distribution if the value of the skewness coefficient is less than $( \pm 1)$. Table 4 shows the results of these tests. As is evident from the results present in Table 4 , no multicollinearity is present between the independent variables, and the values of Variance Inflation Factor of the dimensions are 1.321, 1.240, 1.358, and 1.237, respectively, which are less than 10. As can be seen, the values of Tolerance are between $0.736-0.809$, which is more than 0.05 . The results are an indication that no multicollinearity is present between the independent variables. To ensure that the data were normally distributed, the Skewness coefficients were calculated, and the values were less than \pm 1 indicating normality.

\section{Table 4}

Results of Variance Inflation Factor, Tolerance and Skewness Coefficient

\begin{tabular}{|c|c|c|c|c|}
\hline No. & Independent Variables & VIF & Tolerance & Skewness \\
\hline 1 & Innovativeness & 1.321 & 0.757 & -0.839 \\
\hline 2 & Risk Taking & 1.240 & 0.807 & 0.167 \\
\hline 3 & Proactiveness & 1.358 & 0.736 & -0.784 \\
\hline 4 & Networking & 1.237 & 0.809 & -0.104 \\
\hline
\end{tabular}

\subsection{Results of Hypotheses Testing}

H1: There is a significant positive relationship between intrapreneurial behaviors in commercial banks, and their innovative performance.

A simple linear regression test was conducted to investigate the H1 hypotheses. The results are shown in Table 5. From the table, $(\mathrm{R})$ value represented the correlation and was $79.8 \%$, which indicates that the relationship between the two variables was generally considered a very good correlation. $\left(\mathrm{R}^{2}\right)$ value indicates how much of the total variation in the intrapreneurial behaviors can explain the innovative performance of banks. In this case, $64 \%$ can be explained, while other variables not included in the regression model explain the remaining 36\%. An ANOVA table provides an F-test to determine whether the model is a good fit for the data. According to this p-value, it is. Because $F(1,121$ degrees of freedom $)=12.536, p \leq 0.05)$, which indicates that, overall, the regression model was statistically significant and, thus, a good fit for the relationship between intrapreneurial behaviors and banks innovative performance. The coefficients table provides the necessary information to predict the innovative performance of banks from various intrapreneurial behaviors, as well as determine whether intrapreneurial behaviors contribute statistically significantly to the model. Besides, beta values for intrapreneurial behaviors reached 0.798 , which indicates that $79.8 \%$ of the innovative performance of banks from intrapreneurial behaviors. In other words, the results can interpret as for every unit increase in intrapreneurial behaviors, a 79.8\% increase in the predicted innovative performance of the banks occurred. Based on these results, the null hypothesis should be rejected, and the hypothesis accepted.

\section{Table 5}

Simple Linear Regression Analysis to ensure the Impact of Intrapreneurial Behaviors on the Innovative Performance of Banks

\begin{tabular}{|c|c|c|c|c|c|c|c|c|c|}
\hline \multirow{2}{*}{$\begin{array}{l}\text { Dependent } \\
\text { Variable }\end{array}$} & \multicolumn{3}{|c|}{ Model Summary } & \multirow{2}{*}{$\frac{\text { ANOVA }}{\text { F }}$} & \multicolumn{5}{|c|}{ Coefficient } \\
\hline & $\mathbf{R}$ & $\mathbf{R}^{2}$ & $\mathbf{R}^{2}$ Adjusted & & df & Sig. & $\beta$ & $\mathbf{t}$ & Sig. \\
\hline
\end{tabular}


The H1 hypothesis included four sub hypotheses:

H1a: There is a significant positive relationship between innovativeness in commercial banks, and their innovative performance.

$\mathrm{H} 1 \mathrm{~b}$ : There is a significant positive relationship between risk-taking in commercial banks, and their innovative performance.

H1c: There is a significant positive relationship between proactiveness in commercial banks, and their innovative performance.

H1d: There is a significant positive relationship between networking in commercial banks, and their innovative performance.

To test these hypotheses, the researcher used multiple regression analysis to ensure the impact of Intrapreneurial Behaviors dimensions (innovativeness, risk-taking, proactiveness, and networking) on the innovative performance of banks, which are shown in Table 6.

\section{Table 6}

Multiple Regression Analysis shows the Impact of Intrapreneurial Behavior Dimensions on the Innovative Performance of Banks

\begin{tabular}{|c|c|c|c|c|c|c|c|c|c|c|}
\hline Dependent Variable & (R) & $\left(\mathbf{R}^{2}\right)$ & $\mathbf{R}^{2}$ Adjusted & $\mathbf{F}$ & DF & Sig* & B & & $\mathbf{T}$ & Sig* \\
\hline \multirow{4}{*}{$\begin{array}{l}\text { Innovative } \\
\text { Performance of Banks }\end{array}$} & \multirow{4}{*}{0.804} & \multirow{4}{*}{0.65} & \multirow{4}{*}{0.63} & & & \multirow{4}{*}{0.000} & Innovativeness & 0.206 & 2.404 & 0.017 \\
\hline & & & & & 4 & & Risk Taking & 0.148 & 1.319 & 0.189 \\
\hline & & & & \multirow{2}{*}{12.535} & 237 & & Proactiveness & 0.208 & 2.704 & 0.007 \\
\hline & & & & & 241 & & Networking & 0.271 & 1.361 & 0.030 \\
\hline
\end{tabular}

Note: The impact is significant at $1(\alpha \leq 0.05)$.

Table 6 shows the impact of intrapreneurial behavior dimensions (innovativeness, risk-taking, proactiveness, and networking) on the innovative performance of banks. The regression model achieves a high degree of fit, as reflected by $(R)$ and $\left(R^{2}\right)$ values of (0.804) and (0.65) respectively, which suggests that $65 \%$ of the explained variation in innovative performance of banks could account for Intrapreneurial behaviors (innovativeness, risk-taking, proactiveness, and networking). On the other hand, Table 6 for the executive data set indicated the slope value of $(0.206),(0.148),(0.208)$, and $(0.271)$ for the regression line. The results suggest that for a one-unit increase in intrapreneurial behaviors (innovativeness, risk-taking, proactiveness, and networking) significantly predicts a $(20.6 \%)(14.8 \%)(20.8 \%)$, and (27.1\%) increase in the innovative performance of banks. Table 6 shows that the analysis of variance of the fitted regression equation was significant with an $\mathrm{F}$ value of (12.535). This value is an indication that the model is a good one. The p-value of $(\alpha \leq 0.05)$ shows a statistically significant relationship between the variables at a 0.9 confidence level. The results also indicate that intrapreneurial behaviors (innovativeness, risk-taking, proactiveness, and networking) impact the innovative performance of banks with a coefficient of 0.206) for innovativeness. 0.148 For risk-taking, 0.208 for proactiveness, and 0.271 for networking. Thus, intrapreneurial behaviors (innovativeness, proactiveness, and networking) impact the innovative performance of banks. Therefore, the hypothesis is accepted, and the null hypothesis is rejected. For Risk-Taking factor P-value was more than 5\%, hypothesis is rejected, and the null hypothesis is accepted.

H2: There is a significant positive relationship between good characteristics of banking employees, and the impact of intrapreneurial behaviors on the innovative performance of commercial banks.

Hierarchical Multiple Regression analysis was used to ensure the moderate impact of employees' characteristics on the relationship between Intrapreneurial behaviors and the innovative performance of banks in Jordan. The results are shown in Table 8.

\section{Table 8}

Hierarchical Multiple Regression Analysis

\begin{tabular}{|c|c|c|c|c|c|c|c|}
\hline \multirow{2}{*}{$\begin{array}{l}\text { Dependent } \\
\text { Variable }\end{array}$} & \multirow{2}{*}{ Independent Variables } & \multicolumn{3}{|c|}{ Model 1} & \multicolumn{3}{|c|}{ Model 2} \\
\hline & & $\mathbf{B}$ & $\mathbf{T}$ & Sig* & $\boldsymbol{\beta}$ & $\mathbf{T}$ & Sig* \\
\hline \multirow{7}{*}{$\begin{array}{l}\text { Banks Innovative } \\
\text { Performance }\end{array}$} & Intrapreneurial behaviors & 0.798 & 6.218 & 0.000 & & & \\
\hline & Intrapreneurial behaviors $\times$ Employees Characteristics & & & & 0.645 & 4.703 & 0.001 \\
\hline & $\mathrm{R}$ & 0.798 & & & 0.824 & & \\
\hline & $\mathrm{R}^{2}$ & 0.640 & & & 0.679 & & \\
\hline & $\Delta \mathrm{R}^{2}$ & 0.640 & & & 0.039 & & \\
\hline & $\Delta \mathrm{F}$ & 12.536 & & & 26.129 & & \\
\hline & $\Delta \mathrm{F} \mathrm{Sig.}$ & 0.000 & & & 0.001 & & \\
\hline
\end{tabular}

Note: ${ }^{*}$ The effect is significant at level $(\alpha \leq 0.05)$.

Table 7 shows the moderate impact of employees' characteristics on the relationship between intrapreneurial behaviors and the innovative performance of banks in Jordan. The first model had a value of $\mathrm{R}=0.798$ for the correlation coefficient; this 
demonstrates a positive correlation between intrapreneurial behaviors and the innovative performance of banks. The results also show the statistically significant impact of intrapreneurial behaviors on the innovative performance of banks, with an $\mathrm{F}$ value of 12.536 with a p-value of less than 0.05 . As the value of the coefficient of determination is $\mathrm{R}^{2}=0.64$, this indicates that intrapreneurial behaviors explain $(64.0 \%)$ of the variance of the innovative performance of banks. In the second model, the entry of the moderate variable (employees characteristics) to the regression model increased the value of the correlation coefficient ( $\mathrm{R}$ $=0.824)$, and the value of the coefficient of determination $\left(\mathrm{R}^{2}\right)$ increased $(0.039)$. This percentage was statistically significant, where the value of $(\Delta \mathrm{F}=26.129)$ and the significance level (Sig. $\Delta \mathrm{F}=0.001)$, which is less than $(0.05)$. As the slope value $(\beta=$ 0.645 ) of employees' characteristics and the (t Calculate) value was 4.703 because the p-value was less than 0.05 . The result confirms that a statistically significant impact of employees' characteristics (moderating variable) on the relationship between intrapreneurial behaviors and the innovative performance of banks, where the percentage of interpretation of variation in the innovative performance of banks has improved, and the percentage increased from $64.0 \%$ to $67.9 \%$. Based on this result, the second alternative hypothesis is accepted, and the null hypothesis is rejected. Thus, the greater the employees banking characteristics in banks, the stronger the impact of intrapreneurial behaviors on the innovative performance of banks.

\subsection{Research Model}

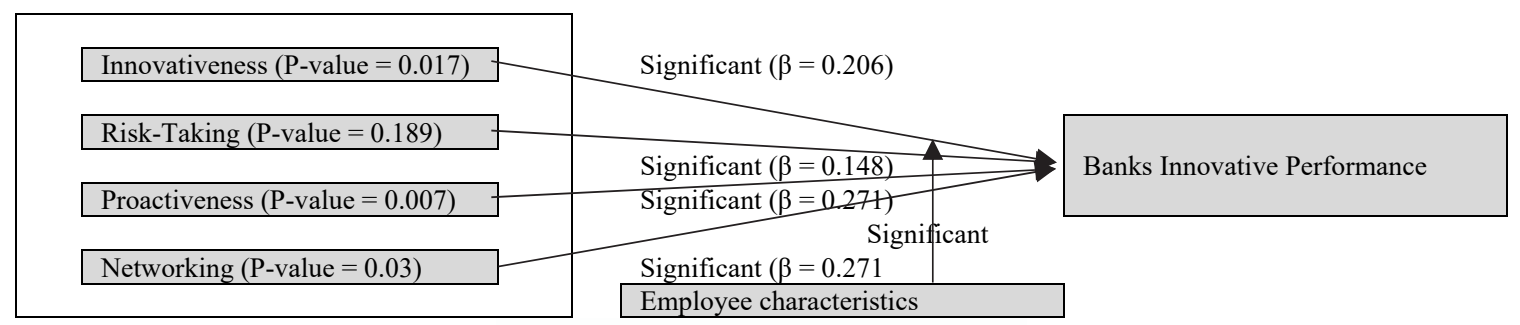

Fig. 2. The model of the study results.

\section{Research Discussion}

The hypotheses of this study were posited as following one general hypothesis and four sub-hypotheses:

\section{General hypothesis:}

The greater the employees' good characteristics in banks, the stronger the impact of intrapreneurial behaviors on the innovative performance of banks in Jordan.

The results of this study show the relationship between intrapreneurial behaviors of bank employees and the innovative performance of banks via the moderating role of employees' characteristics (general hypothesis). The results found a positive impact of intrapreneurial behaviors of employees on the innovative performance of banks moderating role of employees' characteristics. These results of the current research were as expected, if an employees has a high level of intrapreneurial behavior in the bank, then this behavior can improve the bank's innovative performance, including the development of new products or new methods. Conversely, banks with fewer entrepreneurial staff exhibit low innovative performance/ this, the opportunity for success for banks that have entrepreneurial employees, will be higher than banks that do not have entrepreneurial employees.

\section{Sub-hypotheses}

H1a: There is a significant positive relationship between innovativeness in commercial banks, and their innovative performance.

Innovative ideas increase the ability of the organization to respond to opportunities and develop competitive advantages (Oldham and Cummings, 1996). This current research included five statements to measure the importance of innovativeness among employees within banks. The highest rank was "If I were able to contribute more ideas, it would motivate me more to stay in my bank." This was rank 1 . This demonstrates an employee's interest in spreading his/her ideas to the bank's management and applying good ideas that benefit the bank. On the other hand, the question "There is a specialized committee in my bank that receives and evaluates creative ideas" was classified with a rank of 6 , meaning that the current banks in Jordan suffer from a lack of a specific entity whose task is to find and extract innovative ideas from employees. This occurred despite the agreement that the innovative ideas of employees are critically based on the results of this research. Trust and attention are powerful and influential factors in innovation, as they help to overcome possible obstacles to innovation. 
$\mathrm{H} 1 \mathrm{~b}$ : There is a significant positive relationship between risk-taking in commercial banks, and their innovative performance.

It became apparent that the question "I will always be determined to accept the challenge" ranked highest, while the question "The term risk-taker considered a positive attribute for people in my bank" had the lowest rank.

When an entrepreneurial employee in a bank indicates that a new way of work or a new product should be created, the actual result is entirely unknown. Although the result may very well be positive, the result also may be negative. This means that researchers should determine the reasons that lead others to judge that the assumption of a risk is negative and to expand the meaning of the concept of risk-taking to help the development of the banking industry in Jordan.

H1c: There is a significant positive relationship between proactiveness in commercial banks, and their innovative performance.

The ranking of the answers for the statement "I feel driven by my values" was superior to the answers for the statement, "There are abundant opportunities that await me".

This demonstrates the connection between the findings of this current study and the behavior of entrepreneurs in motivating themselves and others in a business environment. However, this demonstrates that an employee has principles that help him to do things before others recognize them. But the downside is the lack of opportunities waiting for the employees, and this indicates a lack of opportunities in the market and the lack of appreciation of the employees to the qualities that lead him to a better level; thus, the results obtained by this study are as expected.

H1d: There is a significant positive relationship between networking in commercial banks, and their innovative performance.

The highest-ranked statement was, "It is not a problem for me to know people from different cultures", whereas the statement "I contact with new friends through social media" received the lowest rank.

This result shows that a bank employee has the desire to meet more people from the same culture or more cultures. This process helps an employee to develop his/her communication skills and ease of access to people in an open society with interrelated people. The downside is that people do not communicate with each other through social media because social media is very prevalent, and there are many alternatives, like phone and phone programs.

H1: There is a significant positive relationship between intrapreneurial behaviors in commercial banks, and their innovative performance.

This research and analysis demonstrate the existence of maturity between intrapreneurial behaviors about the requirements for driving the innovative performance of banks, in which a lack of ability to motivate themselves and others was observed. Internal entrepreneurship comprises multiple levels that vary from person to person in terms of individual behavior. When institutions are aware of how individual behavior leads to innovation, this knowledge leads to an improvement in the organization's innovation level by motivating staff to contribute useful ideas. There are factors such as innovativeness, risk-taking, proactiveness, and networking that may be important in the process. The strength of a person's association with the team may be influential on the team as a whole and the strength of performance.

H2: There is a significant positive relationship between good characteristics of banking employees, and the impact of intrapreneurial behaviors on the innovative performance of commercial banks.

This research focused on the most essential qualities that a bank employee's possesses, which have a significant impact on innovation in banks. These qualities are an organized personality, including the meaning of matters related to business, responsibility, and attention to more than one thing at a time. In the context of this study, the results of the three statements were examined. The order of importance is as follows: 1) "I can deal with many responsibilities." 2) I can be effective in the management of multiple operations," and 3) "I can deal with the enormous pressures." The second characteristic in terms of importance was effective communication. This measured the communication skills of the employees, whether with clients or with management and other employees, whether social or even financial communication and documents. The order of importance is as follows: 1) "I have excellent written and oral communication skills," and 2) "I can communicate financial matters to my colleagues without any confusion." 
The third characteristic that achieved the lowest order was alertness and awareness. This attribute measures vigilance towards the financial system or any threat or opportunity to affect it. The order of importance is as follows: 1) "I am always alert to any threat to the financial system." and 2) "I am always aware of changes in the financial sector".

\section{Conclusion}

This research has investigated the relationship between intrapreneurial behavior, the innovative performance of banks, and the personal characteristics of bank employees in Jordan. It was the first of its kind to be conducted in Jordan. The intrapreneurial behaviors addressed in the research were innovativeness, risk-taking, proactiveness, and networking. The moderator that addressed in the research was employees' characteristics. The current research studied the effect of previous intrapreneurial behaviors on the innovative performance of banks, moderating role of employees' characteristics. Intrapreneurial behaviors have been defined as recognizing the employee's opportunities and exploiting them that lead to creating a new competitive power, new product, service, or method of work that improves the organization's performance (Gagné \& Deci, 2005). Innovativeness has many definitions, but in general, all its definitions indicate new products, new services, new strategies, and new ideas, which are done in a novel way. When a company or bank has innovative employees, production will be better, and it is possible to change the way of working for the better (Chen, et al., 2015). Risk-taking is known as the search for courageous suggestions for the benefit of an organization, in which the results of these proposals are uncertain. Risk-taking is an essential part of encouraging employees to be creative (Dai, et al., 2014). Proactiveness is defined as a futuristic vision and seeking opportunity by observing current trends and anticipating future market demands. Proactive employees should be encouraged to develop their behavior to communicate more. (Sebora \& Theerapatvong, 2010). Networking is communicating and contacting others. Employees networking can impact their roles and participation in the company's strategy process. This essential role in communicating with others inspires employees to increase their articulation of opportunities for strategic innovation by aggregating references, familiarity, and networks (Zdroik \& Babiak, 2017). Employees' characteristics are features or qualities belonging typically to employees. This current research addressed employees' characteristics that play crucial roles in achieving more significant benefits for the bank. These characteristics are organized personality, which means that employees have the mental strength to create robust, motivating core beliefs; effective communication, which means verbal speech or other methods of relaying information that get the point across; and alertness and awareness. Alertness means a state of careful watching and readiness especially for danger or opportunity, and awareness means concern about and well-informed interest in a particular situation or development (Kim and Sikula, 2005). The innovative performance of banks means addressing challenges in financial performance, as banks need to adopt new ways to penetrate deeper into the lives and habits of retail and customer customers (Ramlall, 2018). Identifying intrapreneurial behaviors is vital, as this search explores the deep causes of our choices. Improving the innovative performance of a bank requires an understanding of the relationships between and among bank employees and between the organization and employees and how these relationships impact bank performance (Farrukh, et al., 2017). The current research found the strong creative qualities that bank employees have, which should be invested in to develop the bank, and also found the poor creative qualities of bank employees, which must be strengthened to develop the bank and achieve the best results. This research also found that the environments of commercial banks are not all similar. This study examined the extent of intrapreneurial behaviors of employees through their characteristics and the availability of an innovative work environment.

\section{Implications}

Many exciting avenues for further research are opened up due to the findings of this study. Likewise, there are many important implications for managerial and policymakers.

\subsection{Policy Implications}

Jordan has an Association of Jordanian Banks, which maintains a leading role as one of the most efficient banking associations in the region in terms of providing services to member banks to support their capabilities and enabling them to maximize their contributions to achieving sustainable development in the Kingdom (Association of Banks in Jordan, 2018). There is also another entity that has an impact on banks in Jordan. This entity is the Central Bank of Jordan whose vision is to: maintain the monetary stability represented by the stability of the Jordanian dinar exchange rate and the stability of the general level of prices and contribute to providing an attractive investment environment and stimulating economic and social development through the provision of an appropriate interest rate structure and the application of partial and macro-prudential control policies that contribute to achieving banking and financial stability (Central Bank of Jordan, 2018). One recommendation of this current study that greater cooperation should be developed between Central Bank of Jordan, Association of Banks, and commercials banks in Jordan, with regard to innovative performance, through knowledge of the appropriate environment for banks, and encouraging employees, whether financially or in terms of incubators of innovative ideas, or by not imposing penalties on innovative ideas that have not succeeded. This cooperation will serve as a reminder to commercial banks in Jordan to pay attention to innovative performance because of its benefits for employees, banks, and the Jordanian economy as a whole. 


\subsection{Theoretical implications}

The results of this research confirmed a significant and positive effect of intrapreneurial behaviors on the innovative performance of banks. This research contributes to the academic and practical knowledge as one of the first attempts to investigate the impact of intrapreneurial behaviors on the innovative performance of banks. In addition to recognizing the intrapreneurial behaviors that improve innovative performance, this research integrates, refines, and extends the empirical work conducted in the field of the innovative performance of banks in Jordan.

\subsection{Managerial implications}

Determination a specific sales targets or figures can be counterproductive, and intimidation is also unlikely to produce desired results. The way people are assigned to their jobs can motivate them to work hard, and have a good sense of purpose. Workers who believe in fulfilling a task as part of a team have solved more problems, remembered more than they learned, and worked more time than others. The manager should not focus on what should be avoided, or on the wrong methods to motivate employees. Instead, consider what you should do. In some cases, this means being a role model rather than a speech. Lectures aimed at motivating employees are often negligible, or perceived as dishonest.

To reduce practices the violate the rights of workers in the workplace and to build a psychologically favorable working environment, with positive and correct practices.

Innovative leaders outperform others in risk management, try new approaches, follow logical procedures in dealing with negative expectations, and plan to minimize risk.

The most innovative leaders show their aspiration to develop their knowledge, and are learning new skills and information that are consistent with business goals, giving them a competitive edge and encouraging staff to try new approaches.

Innovative leaders are more inclined to take the lead, turn difficult circumstances into opportunities by taking responsibility for important decisions, and are keen to engage others in meetings and debates with serious implications without avoiding divergent views. Innovative leaders are good at anticipating potential obstacles without being over-analyzed, are able to work independently for long periods, have minimal support, and are quick to change direction to exploit new opportunities.

\section{Recommendations for Further Researches}

This research did not deal with the impact of the circumstances in which the neighboring areas of Jordan impact the innovative performance of banks. However, research should be conducted, knowing that these areas can have significant positive and negative impacts. Because the areas surrounding Jordan are experiencing instability, this may affect the economy. Also, the events in areas surrounding Jordan have the potential to create severe impacts. Therefore, additional research should be conducted to determine the impact of the circumstances surrounding Jordan on the characteristics of employees and their intrapreneurial behaviors and their impacts on the innovative performance of commercial banks in Jordan. This research did not deal with impact of the innovative IT applications on innovative performance of commercial banks. Therefore, additional research should be conducted to determine the impact of the innovative IT applications on the employees and their intrapreneurial behaviors and their impacts on the innovative performance of commercial banks in Jordan.

\section{Research Limitations}

As with any study, various challenges and limitations were encountered. The primary limitations were confronted with the mechanism of the research, which included disseminating and collecting the surveys. Some bankers refused to complete the survey, while others accepted the survey but did not return it, and others did not answer the questionnaire completely. However, the sample size was sufficient for analysis. Importantly. Responses were received only from bankers who were willing to respond. Thus, the argument could be made that those bankers who are naturally less accommodating or open to self-analysis or introspection did not respond. Not responding may have an impact on the results, as those who are more accommodating may be more willing to listen to others, more open to suggestion, more self-aware, for instance. Further research will be required.

\section{References}

Afsar, B., \& Umrani, W. (2019). Transformational leadership and innovative work behavior. European Journal of Innovation Management, Vol. ahead-of-print No. ahead-of-print.

Afshar Jahanshahi, A., Nawaser, K., \& Brem, A. (2018). Corporate entrepreneurship strategy: An analysis of top management teams in SMEs. Baltic Journal of Management, 13(4), 528-543. 
Alpkan, L., Bulut, C., Gunday, G., Ulusoy, G., \& Kilic, K. (2010). Organizational support for intrapreneurship and its interaction with human capital to enhance innovative performance: Management Decision, 48(5), 323755.

Alt, E., \& Craig, J. B. (2016). Selling issues with solutions: Igniting social intrapreneurship in for-profit organizations. Journal of Management Studies, 53(5), 794-820.

Augusto Felício, J., Rodrigues, R., \& Caldeirinha, V. R. (2012). The effect of intrapreneurship on corporate performance. Management Decision, 50(10), 1717-1738.

Association of Banks in Jordan. (2018). Directory of banks operating in Jordan. Retrieved from https://www.abj.org.jo

Berzin, S., Pitt-Catsouphes, M. (2015). Social Innovation from the Inside: Considering the "Intrapreneurship" path. Social Work, $60(4), 360-362$.

Cantillon, R. (2012). Introduction to Richard Cantillon, Essai sur la Nature du Commerce en General, Grete Heinz, trans. Reprinted in Hayek, Economic History. Vol. 3. The Collected Works of F.A. Hayek. W. W. Bartley, III \& Stephen Kresge, eds. Chicago: University of Chicago Press.

Central Bank of Jordan. (2018). Retrieved from http://www.cbj.gov.jo

Chen, M. H., Chang, Y. Y., \& Chang, Y. C. (2015). Entrepreneurial orientation, social networks, and creative performance: Middle managers as corporate entrepreneurs. Creativity and Innovation Management, 24(3), $493-507$.

Dai, L., Maksimov, V., Gilbert, B. A., \& Fernhaber, S. A., 2014. Entrepreneurial orientation and international scope: The differential roles of innovativeness, proactiveness, and risk-taking. Journal of Business Venturing, 29(4), 511-524.

Dickel, P. (2017). The impact of protectability and proactiveness on the environmental performance of new ventures. Corporate Governance: The International Journal of Business in Society, 17(1), 117-133.

Dipboye, R. L. (2018). Groups and teams in organizations. The Emerald Review of Industrial and Organizational Psychology, 369-439. doi:10.1108/978-1-78743-785-220181011

Falcão, P., Saraiva, M., Santos, E., \& Cunha, M. (2018). Big Five personality traits in simulated negotiation settings. EuroMed Journal of Business, 13(2), 201-213.

Farrukh, M., Chong, W. Y., Mansori, S., \& Ramzani, S. R. (2017). Intrapreneurial behaviour: The role of organizational commitment. World Journal of Entrepreneurship Management and Sustainable Development, 13(3), $243-256$.

Fellnhofer, K. (2017). Drivers of innovation success in sustainable businesses. Journal of Cleaner Production, 167, 1534-1545.

Foss, N. J., Lyngsie, J., \& Zahra, S. A. (2015). Organizational design correlates of entrepreneurship: the roles of decentralization and formalization for opportunity discovery and realization. Strategic Organization, 13(1), 32-60.

Gagné, M., \& Deci, E. L. (2005). Self-determination theory and work motivation. Journal of Organizational Behavior, 26(4), $331-362$.

Gemes, K. (2005). Hypothetico-deductivism: Incomplete but not hopeless. Erkenntnis, 63(1),139-147.

Heinze, K. L., \& Weber, K. (2016). Toward organizational pluralism: Institutional intrapreneurship in integrative medicine. Organization Science, 27(1), 157-172.

Hornsby, J. S., Kuratko, D. F., Shepherd, D. A., \& Bott, J. P. (2009). Managers' corporate entrepreneurial actions: Examining perception and position. Journal of. Business Venturing, 24(3), 236-247. doi: 10.1016/j.jbusvent.2008.03.002.

Kaifeng, J., Lepak, D. P., Jia, J. U., \& Baer, J. C. (2012). How does human resource management impact organizational outcomes? A meta-analytic investigation of mediating mechanisms. Academy of Management Journal, 55(6), $1264-1294$.

Kassa, A., \& Raju, R. (2015). Investigating the relationship between corporate entrepreneurship and employees engagement. Journal of Entrepreneurship in Emerging Economies, 7(2), 148-167.

Kelley, D. J., O'Connor, G. C., Neck, H., \& Peters, L. (2011). Building an organizational capability for radical innovation: the direct managerial role. Journal of Engineering and Technology Management, 28(4), 249-267.

Kim, C.W., \& Sikula, A. Sr (2005). The characteristics of necessity in a workplace: A replication study. DIAS Technology Review - The International Journal for Business and IT, 1(2), 20-32.

Kollmann, T., Stockmann, C., Meves, Y., \& Kensbock, J. M. (2017). When members of entrepreneurial teams differ: Linking diversity in individual-level entrepreneurial orientation to team performance. Small Business Economics, 48(4), 843-859.

Laila, U., \& Hanif, R. (2017). The impact of task level demands, workgroup level support and affective commitment on emotional exhaustion among services managers. Humanomics, 33(4), 441-452.

Meng, J., \& Berger, B.K. (2012). Measuring return on investment (ROI) of organizations' internal communication efforts. Journal of Communication Management, 16(4), 332-354.

Minh, S., \& Thanh, T. (2020). Analysis of the impact from non-interest income to the operational efficiency of commercial banks in Vietnam. Management Science Letters, 10(2), 455-462. 
Morris, E. (2010). Dell goes mobile to bolster its employees engagement. PR Week, 13 (2), 14-15.

Morris, M.H., Webb, J.W., \& Franklin, R.J. (2011). Understanding the manifestation of entrepreneurial orientation in the nonprofit context. Entrepreneurship Theory and Practice, 35(5), 947-971.

Mustafa, M., Lundmark, E., \& Ramos, H. M. (2016a). Untangling the relationship between human resource management and corporate entrepreneurship: The mediating effect of middle managers' knowledge sharing. Entrepreneurship Research Journal, 6(3), 273-295.

Neessen, P. C. M., Caniëls, M. C. J., Vos, B., \& de Jong, J. P. (2019). The intrapreneurial employees: Towards an integrated model of intrapreneurship and research agenda. International Entrepreneurship and Management Journal, 15 (2), 545-571. doi:10.1007/s11365-018-0552-1.

Panda, B., \& Leepsa, N. M. (2019). Does institutional ownership engagement matter for greater financial performance? Evidence from a developing market. International Journal of Law and Management, 61(2), 359-383. .doi:10.1108/ijlma-092017-0228.

Parker, S. K., \& Collins, C. G. (2010). Taking stock: Integrating and differentiating multiple proactive behaviors. Journal of Management, 36(3), 633-662.

Pattinson, M., Butavicius, M., Parsons, K., McCormac, A., Calic, D. (2017). Managing information security awareness at an Australian bank: A comparative study. Information and Computer Security, 25(2), 181-189.

Phogat, M. S. (2016). Seven habits of highly successful bankers. Vinimaya, 37(2), 58.

Ramlall, I. (2018). A framework for financial stability risk assessment in banks. The Banking Sector Under Financial Stability, Vol. 3 (pp. 29-117). Bingley, England; Emerald Publishing Limited.

Sebora, T. C., \& Theerapatvong, T. (2010). Corporate entrepreneurship: A test of external and internal impacts on managers' idea generation, risk taking, and proactiveness. International Entrepreneurship and Management Journal, 6(3), 331-350.

Taştan, S.B., \& Güçel, C. (2014). Explaining intrapreneurial behaviors of employees with perceived organizational climate and testing the mediating role of organizational identification: A research study among employees of Turkish innovative firms. Procedia-Social and Behavioral Sciences, 150, 862-871.

Turner, K. L., \& Makhija, M. V. (2006). The role of organizational controls in managing knowledge. Academy of Management Review, 31(1), 198-217.

Van Dam, K., Schipper, M., \& Runhaar, P. (2010). Developing a competency-based framework for teachers' entrepreneurial behaviour. Teaching and Teacher Education, 26(4), 965-971.

Vargas-Halabí,T., Mora-Esquivel, R., \& Siles, B. (2017). Intrapreneurial competencies: Development and validation of a measurement scale. European Journal of Management and Business Economics, 6(1), 86-111.

Wang, Z. and Wang, N. (2012). Knowledge sharing, innovation and firm performance. Expert Systems with Applications, 39(10), 8899-8908.

World Health Organization. (2005). Mental health policies and programs in the workplace. Geneva, Switzerland: World Health Organization.

Young, K. (2018). Enhancing employees communication behaviors for sensemaking and sensegiving in crisis situations. Journal of Communication Management, 22(4), 451-475.

Zdroik, J., \& Babiak, K. (2017). Networking with a purpose: Men and women's perception of career networking in sports NGBs. Sport, Business and Management: An International Journal, 7(3), 234-257.

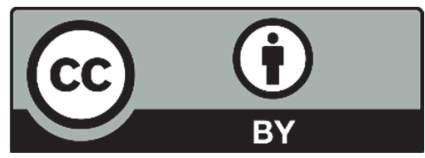

(C) 2020 by the authors; licensee Growing Science, Canada. This is an open access article distributed under the terms and conditions of the Creative Commons Attribution (CC-BY) license (http://creativecommons.org/licenses/by/4.0/). 